\title{
Pengaruh Daya Tanggap, Kehandalan, Jaminan, Empati, Bukti Fisik Kepada Kepuasan Pelanggan Supermarket Sea Mart
}

The Responsiveness, Reliability, Assurance, Empathy and Tangible Affect for Sea Mart Supermarket Customer Satisfaction

\author{
Lu'lu Ul Maknunah \\ Jurusan Ilmu Administrasi Bisnis, Fakultas Ilmu Sosial dan Ilmu Politik, Univ. \\ Islam Balitar \\ J1. Majapahit No. 2 - 4 , Blitar 66139 \\ Email: luluul.maknunah91@gmail.com
}

\begin{abstract}
Abstrak
Supermarket Sea Mart merupakan supermarket terletak di Kota Blitar. Persaingan yang ketat membuat setiap supermarket harus dapat memenuhi kepuasaan pelanggannya. Penelitian ini berada dalam jenis penelitian kuantitatif untuk mencari tahu mengenai pertama daya tanggap, kedua bukti fisik, ketiga empati, keempat jaminan dan kelima kehandalan, (yaitu variabel bebas) yang memiliki pengaruh kepada kepuasan pelanggan (merupakan variabel terikat) di Supermarket Sea Mart. Hasil penelitian didapatkan dengan menyebar kuesioner untuk 100 pelanggan Sea Mart. Berdasarkan pengolahan hasil kuesioner dapat diketahui kelima variabel bebas memberi pengaruh secara simultan dan juga parsial kepada variabel terikat. Pengaruh kelima variabel adalah $71 \%$ kepada variabel terikat.
\end{abstract}

Kata Kunci: Kehandalan, bukti fisik, empati, jaminan, daya tanggap

\section{Abstract}

Sea Mart Supermarket is one of supermarkets in Blitar. Tight competition makes every supermarket to satisfy its customers' satisfaction. The research is a quantitative research to find out affect from assurance, empathy, reliability, tangible, and also responsiveness for Supermarket of Sea Mart customer 
satisfaction. This research was obtained from questionnaires to 100 Sea Mart customers. Based on the questionnaire has been known all of independent variables gave affect for dependent variable partially and also simultaneously. The five independent variables affect to dependent variable about $71 \%$.

Keywords: Reliability, tangible, empathy, assurance, responsiveness,

\section{PENDAHULUAN}

Pada era globalisasi kini menyebabkan persaingan yang ketat antar penyedia produk. Salah satu supermarket penyedia produk yang berkembang di kota Blitar saat ini adalah Supermarket Sea Mart. Supermarket ini ramai setiap hari dan memiliki luas bangunan yang sangat luas. Setiap supermarket diharuskan sanggup membangkitkan kepuasan kepada para pelanggannya. Kepuasaan pelanggan dihasilkan antara lain berdasarkan penawaran dan pelayanan dengan baik, mengingat supermarket harus mampu bertahan pada posisi market-nya di tengah persaingan antar supermarket di kota Blitar.

Perasaan senang ataupun kecewa yang orang rasakan dari manfaat suatu produk merupakan pengertian dari kepuasaan (Kotler, 2008). Oleh karena itu, tingkat kepuasan yang dirasakan seorang pelanggan berbeda-beda karena ukurannya adalah kualitatif dan tidak bias dihitung seberapa besar mereka puas. Kepuasan akan terjadi ketika pelanggan merasa apa yang mereka dapatkan sudah sesuai dengan keinginan mereka. Sebaliknya, jika harapan tidak tercapai maka kepuasaanpun tidak akan muncul.

Dalam menentukan kepuasan pelanggan terdapat lima faktor yang perlu dipertimbangkan penyedia jasa/produk yaitu kualitas produk, pelayanan atau jasa, emosi, biaya serta harga (Lupiyoadi, 2001). Pada penelitian ini, difokuskan pada faktor kualitas pelayanan dari Supermarket Sea Mart Kota Blitar. Supermarket Sea Mart merupakan perusahaan penyedia produk, sehingga sangat penting menilai kepuasaaan pelanggannya dari segi kualitas pelayanan yang diberikan.

Jasfar (2002) mengemukakan bahwa dimensi kualitas jasa terdiri dari lima hal meliputi (1) daya tanggap atau responsiveness diartikan dengan bantuan yang diberikan oleh pegawai ketika konsumen merasa kesulitan, (2) jaminan atau 
assurance adalah sifat-sifat yang diberikan pegawai pada konsumen untuk menghindari keraguan konsumen tersebut, (3) empati (emphaty) dapat diartikan bagaiaman pegawai dapat berkomunikasi personal dan baik terhadap konsumennya, (4) bukti fisik (tangibles) yakni berbentuk fisik yang disediakan pemberiu jasa dalam melakukan proses pemberian jasa, (5) kehandalan atau reliability merupakan kemampuan pegawai dalam memberikan pelayanan prima dan pelayanan yang tepat pada konsumen sesuai yang dijanjikan.

Lima variabel bebas penelitian kali ini terdiri dari variabel $\mathrm{X}_{1}$ yaitu Kehandalan, $\mathrm{X}_{2}$ yaitu Daya Tanggap, $\mathrm{X}_{3}$ yaitu Jaminan, $\mathrm{X}_{4}$ yaitu Empati, $\mathrm{X}_{5}$ yaitu Bukti Fisik serta satu dependent variable Y yaitu Kepuasan Pelanggan. Kerangka pemikiran pada penelitian ini dapat diketahui melalui Gambar 1 dan berdasarkan Gambar 1 tersebut dapat dirumuskan hipotesis penelitian sebagai berikut:

$\mathrm{Ho}_{1}$ Diduga lima independent variable tidak memiliki pengaruh kepada dependent variable yaitu kepuasan pelanggan $(\mathrm{Y})$

$\mathrm{Ha}_{1}$ Diduga lima independent variable memiliki pengaruh kepada dependent variable yaitu kepuasan pelanggan $(\mathrm{Y})$

$\mathrm{Ho}_{2}$ Diduga variabel pertama yaitu kehandalan (X1) tidak memiliki pengaruh secara parsial terhadap variabel kepuasan Pelanggann (Y)

$\mathrm{Ha}_{2}$ Diduga variabel pertama yaitu kehandalan (X1) memiliki pengaruh secara parsial terhadap variabel kepuasan Pelanggann (Y)

Ho3 Diduga variabel kedua yaitu daya tanggap (X2) tidak memiliki pengaruh secara parsial terhadap variabel kepuasan Pelanggan (Y)

$\mathrm{Ha}_{3}$ Diduga variabel kedua yaitu daya tanggap (X2) memiliki pengaruh secara parsial terhadap variabel kepuasan pelanggan $(\mathrm{Y})$ 


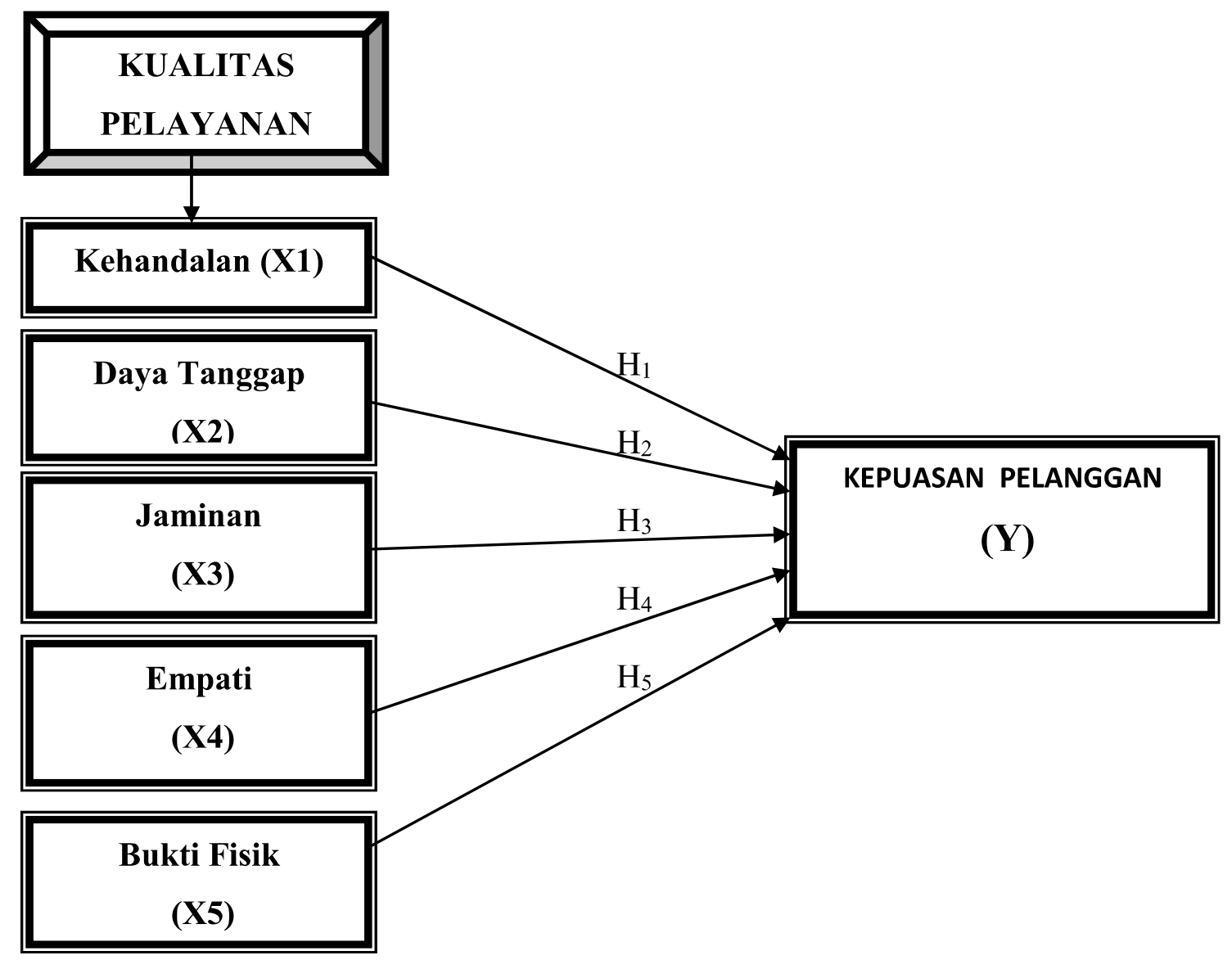

Gambar 1. Kerangka Pemikiran

Ho4 Diduga variabel ketiga yaitu assurance atau jaminan (X3) tidak memiliki pengaruh secara parsial terhadap variabel kepuasan pelanggan $(\mathrm{Y})$

Ha4 Diduga variabel ketiga yaitu assurance atau jaminan (X3) memiliki pengaruh secara parsial terhadap variabel kepuasan pelanggan $(\mathrm{Y})$

Ho5 Diduga variabel keempat yaitu empati (X4) tidak memiliki pengaruh secara parsial terhadap variabel kepuasan pelanggan (Y)

$\mathrm{Ha}_{5}$ Diduga variabel keempat yaitu empati (X4) memiliki pengaruh secara parsial terhadap variabel kepuasan pelanggan (Y)

Ho6 Diduga variabel kelima yaitu bukti fisik (X5) tidak memiliki pengaruh secara parsial terhadap dependent variabel (Y)

$\mathrm{Ha}_{6}$ Diduga variabel kelima yaitu bukti fisik (X5) memiliki pengaruh secara parsial terhadap dependent variabel (Y) 


\section{METODE PENELITIAN}

Penelitian kuantitatif merupakan penelitian yang dipakai kali ini. Menurut Hermawan (2005), penelitian yang bersifat obyektif, mencakup penelitian pengumpulan dan analisis data kuantitatif serta diolah secara statistic adalah pengertian dari penelitian kuantitatif. Pengolahan hasil kuesioner diolah menggunakan bantuan alat atau aplikasi SPSS versi 18. Menurut Nugroho (2005) SPSS atau dikenal dengan Statistical Package for Social Science merupakan salah satu program dalam penelitian statistik untuk membantu pengolahan, perhitungan dan analisis data secara statistik.

Hasil olahan data penelitian ini bersumber dari dua jenis data yang berbeda. Keduanya adalah primer dan sekunder. Informasi-informasi yang terkait pada penelitian ini secara langsung dari sumber asli merupakan jenis data primer. Hasil kuesioner yang diberikan pada pelanggan Sea Mart termasuk dalam data primer. Data kedua yaitu sekunder adalah informasi-informasi terkait penelitian ini yang didapat secara tidak langsung. Sumber data kedua (data sekunder) dari penelitian ini adalah data-data yang masih berhubungan dengan penelitian ini antara lain bersumber dari buku, jurnal penelitian, maupun dari penelitian terdahulu.

Kuesioner dibagikan pada pelanggan Supermarket Seamart yang menjadi sampel. Menurut Umar (2002) sampel adalah bagian dari populasi. Jumlah ratarata pengunjung per minggu di Supermarket Sea Mart adalah kurang lebih 350 orang dalam bulan Juli 2017. Angka tersebut digunakan sebagai jumlah populasi konsumen di Supermarket Seamart. Banyaknya sampel data yang diperlukan dapat ditentukan dengan rumus Slovin (Hasan, 2002): $\mathbf{n}=\mathbf{N} /\left(\mathbf{1}+\mathbf{N} \cdot \mathbf{e}^{2}\right)$

$\mathrm{n}=$ Ukuran Sampel

$\mathrm{N}=$ Ukuran Populasi

$\mathrm{e}=$ Persentase keloggaran ketidaktelitian yang dikarenakan kesalahan pengambilan sampel yang masih dapat ditolerir.

Tingkat kesalahan yang digunakan adalah $10 \%$.

$\mathrm{n}=350 /(1+350 \times 0,1 \times 0,1)$

$\mathrm{n}=77,78$

Sampel yang digunakan sebesar 100 responden (hasil pembulatan 77,78). 
Teknik sampling untuk penelitian kali ini yakni teknik accidental samplnig. Menurut Arikunto (2002), accidental sampling adalah teknik dalam usaha pengambilan sampel secara kebetulan, yaitu siapapun yang secara kebetulan bertemu dengan peneliti dapat digunakan sebagai sampel bila yang kebetulan ditemui tersebut cocok digunakan sebagai pemberi informasi. Kriteria cocok yang dimaksud pada penelitian ini adalah pelanggan Sea Mart yang sedang berbelanja di Supermarket Sea Mart dan sudah datang ke Supernarket Sea Mart lebih dari tiga kali kunjungan.

Kuesioner/angket adalah teknik pengumpulan data yang dilakukan dengan memberi seperangkat pernyataan atau pertanyaan tertulis kepada responden untuk diisi/dijawab (Sugiono, 2013). Kuesioner pada penelitian ini diberikan pada pelanggan Supermarket Sea Mart sebagai responden yang telah dipilih. Kuesioner terdiri dari 20 butir pernyataan yang mewakili lima independent variable dan satu variabel terikat dengan pengukuran kuesioner yang terdiri dari skala interval terendah yaitu : (1) Sangat Tidak Setuju (STS) ; (2) Tidak Setuju (TS) ; (3) Netral (N) ; (4) Setuju (S) ; (5) Sangat Setuju (SS).

Menurut Parjanti dkk. (2014), hasil kuesioner seharusnya diuji menggunakan beberapa uji meliputi uji instrumen, uji asumsi klasik dan uji hipotesis. Menurut Bahri dan Zamzam (2015), uji instrumen perlu dilakukan ketika instrument tesebut merupakan instrumen yang baru dibuat dan perlu diuji validitas dan juga reliabilitasnya. Uji asumsi klasik yang biasanya digunakan sebagai prasyarat suatu analisis data adalah uji normalitas, uji autokorelasi, uji multikolinearitas dan uji heteroskedastisitas (Hamdi dan Bahruddin, 2014). Menurut Soegoto (2013), uji hipotesis adalah uji yang dilakukan untuk menganalisis data hasil riset dan membuktikan hipotesis mana yang akan diterima. Langkah-langkah pengujian hasil penelitian dapat dilihat pada Gambar 2. 


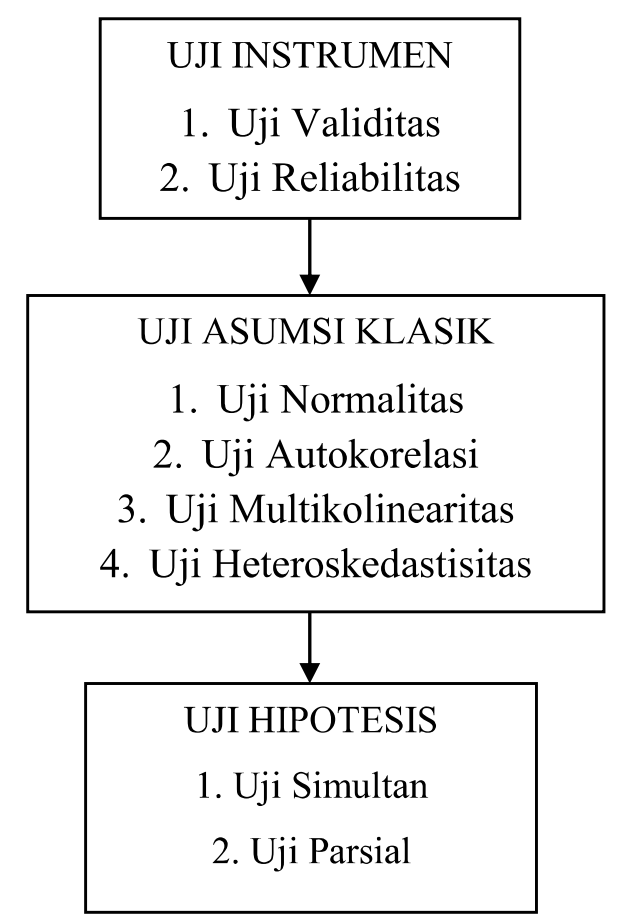

Gambar 2. Langkah-Langkah Pengujian Hasil Penelitian

Menurut Ghozali (2006), uji validitas berarti cara untuk mengukur valid tidaknya suatu kuesioner. Sebuah kuesioner dikatakan valid jika pertanyaan atau pernyataan pada kuesioner itu sanggup mengungkapkan sesuatu yang akan diukur menggunakan alat ukur (kuesioner) itu. Trihendradi (2013) menyatakan uji validitas menggunakan Total Pearson Correlation yang apabila nilai Sig. (2tailed $\leq$ 0,05 maka dikatakan instrument valid.

Menurut Ghozali (2006), uji Reliabilitas adalah alat untuk mengukur kehandalan suatu kuesioner. Kuesioner dikatakan handal jika memberikan hasil yang konsisten meskipun dilakukan pengambilan jawaban berulang-ulang. Pednapat Sugiyono (2005), terkait nilai yang dipakai untuk mengukur reliabilitas alat ukur adalah Alpha Cronbach. Alat ukur (kuesioner) tersebut dikatakan reliable jika nilai cronbach alpha $>0.6$.

Uji selanjutnya yang diberikan kepada data antara lain uji asumsi klasik yang meliputi uji normalitas, autokorelasi, heteroskedastisitas dan multikolinieritas. Menurut Budiantara (2014), uji normalitas perlu diberikan untuk mengetahui apakah data pada sampel yang digunakan berasal dari populasi yang 
terdistribusi secara normal/tidak. Uji normalitas dapat dilakukan menggunakan beberapa cara, diantaranya dengan nilai skewness dan kurtosis. Menurut Nisfiannoor (2009), data berdistribusi normal jika nilai rasio skewness dan kurtosis antara -2 hingga +2 . Nisfiannoor dan Valentini (2006) menyebutkan bahwa nilai rasio skewness didapatkan dari membagi nilai skewness dengan nilai standard error skweness. Nilai rasio kurtosis juga didapatkan dari membagi nilai kurtosis dengan nilai standard error kurtosis.

Uji autokorelasi merupakan salah satu uji asumsi klasik yang memiliki maksud untuk menguji asumsi dalam regresi di mana variabel dependent tidak berkorelasi dengan nilai variabel itu sendiri. Artinya, nilai dari variabel dependent tidak behubungan dengan variabel itu sendiri, baik dari periode sebelumnya (t-1) maupun periode sesudahnya (T) (Santosa dan Ashari, 2005). Menurut Singgih (2002) dalam Sulistiyawan (2008), ada tidaknya masalah autokorelasi dapat dilihat melalui nilai Durbin-Watson, dimana:

1. D-W dibawah -2, mengindikasikan autokorelasi positif.

2. D-W diatas +2 , mengindikasikan autokorelasi negatif.

3. D-W diantara -2 sampai dengan +2 , mengindikasikan tidak ada autokorelasi.

Uji asumsi klasik lainnya yaitu uji multikolinearitas yang dilakukan untuk mengetahui tidak terjadi hubungan yang sangat kuat atau tidak terjadi hubungan linier yang sempurna atau dapat pula dikatakan juga bahwa antar variabel bebas tidak terkait satu sama lain (Zulfikar, 2016). Menurut Siswanto (2015), untuk mengetahui ada tidaknya masalah multikolinearitas dilihat berdasarkan nilai VIF (Variance Inflation Factor) di mana jika nilai VIF tidak melebihi 10 maka masalah multikolinearitas tidak terjadi pada model regresi tersebut.

Uji heteroskedastisitas bertujuan untuk menguji apakah dalam model regresi terjadi ketidaksamaan variance dari residual satu pengamatan ke pengamatan yang lain (Siregar, 2013). Uji heteroskedastisitas dapat dilakukan dengan uji Glejser. Uji Glejser meregresikan variabel independen dengan nilai absolut residualnya. Model regresi yang baik ketika hasilnya tidak terjadi masalah heteroskedastisitas. Ketentuan uji Glejser yaitu (Gujarati, 2004):

a. Jika nilai sig $>0,05$ maka tidak terjadi masalah heteroskedastisitas. 
b. Jika nilai sig $<0,05$ maka terjadi masalah heteroskedastisitas.

Menurut Algifari (2003) dalam Setyani (2015), uji F atau uji serempak dilakukan untuk mengetahui pengaruh variabel independen secara simultan (serempak) terhadap variabel dependen. Menurut Nugroho (2005), cara untuk mengetahui ada tidaknya pengaruh signifikan pada uji F, yaitu:

a. Jika nilai Sig $<0,05$ maka variabel independen secara simultan berpengaruh signifikan terhadap variabel dependen.

b. Jika nilai Sig $>0,05$ maka variabel independen secara simultan tidak berpengaruh signifikan terhadap variabel dependen.

Uji $\mathrm{T}$ diguanakan untuk mengetahui pengaruh masing-masing variabel independen secara individual (parsial) terhadap variabel dependen (Siregar, 2013). Pengaruh parsial dapat diketahui dengan cara (Santosa, 2008):

1. Jika nilai Sig $<0,05$ maka variabel bebas memiliki pengaruh secara parsial terhadap variabel terikat.

2. Jika nilai Sig $>0,05$ maka variabel bebas tidak memiliki pengaruh secara parsial terhadap variabel terikat.

Koefisien determinan $\left(\mathrm{R}^{2}\right)$ digunakan untuk mengetahui seberapa besar kemampuan variabel independen dapa menjelaskan variabel dependen (Sugiyono, 2011). Nilai dari determinan coefficient antara nol sampai dengan satu $\left(0<\mathrm{R}^{2}<\right.$ 1). Nilai $\mathrm{R}^{2}$ yang kecil berarti kemampuan variabel independen dalam menjelaskan variasi dependen sangat terbatas, sedangkan nilai $\mathrm{R}^{2}$ yang mendekati satu berarti variabel-variabel independen memberikan hampir semua informasi yang dibutuhkan guna memprediksi dependent variable (Ghozali, 2009 dalam Ma'arif, 2013).

\section{HASIL DAN PEMBAHASAN}

\section{Uji Instrumen}

Terdapat dua uji pada uji instrumen yaitu uji validitas dan uji reliabilitas. Pada penelitian ini, hasil uji validitas dan uji reliabilitas dapat dilihat pada Tabel 1. Nilai Sig. (2-tailed) menunjukkan angka 0,000 untuk semua item pertanyaan, sehingga dapat ditarik kesimpulan bahwa keseluruhan item pertanyaan sudah 
valid. Hal tersebut berdasarkan pendapat Trihendradi (2013) yang menyatakan jika nilai Sig. (2-tailed) $\leq 0,05$ maka dikatakan instrument valid. Menurut Sugiyono (2005), kuesioner dikatakan reliable jika nilai cronbach alpha lebih dari 0,6. Hasil uji reliabilitas pada Tabel 1 menunjukkan nilai lebih dari 0,6 untuk semua variabel bebas dan terikat. Nilai tersebut menunjukkan bahwa instrumen pada penelitian ini dapat dikatakan reliable atau handal.

Tabel 1. Hasil Uji Validitas dan Uji Reliabilitas

\begin{tabular}{|c|c|c|c|c|c|}
\hline Variabel & Kode Item & Sig. (2-tailed) & Hasil & $\begin{array}{c}\text { Cronbach's } \\
\text { Alpha }\end{array}$ & Hasil \\
\hline \multirow{3}{*}{$\begin{array}{l}\text { Kehandalan } \\
\text { (X1) }\end{array}$} & $\mathrm{X} 1.1$ & 0,000 & Valid & \multirow{3}{*}{0,610} & Reliable \\
\hline & $\mathrm{X} 1.2$ & 0,000 & Valid & & Reliable \\
\hline & $\mathrm{X} 1.3$ & 0,000 & Valid & & Reliable \\
\hline \multirow{3}{*}{$\begin{array}{l}\text { Daya } \\
\text { Tanggap } \\
(\mathrm{X} 2)\end{array}$} & $\mathrm{X} 2.1$ & 0,000 & Valid & \multirow{3}{*}{0,628} & Reliable \\
\hline & $\mathrm{X} 2.2$ & 0,000 & Valid & & Reliable \\
\hline & $\mathrm{X} 2.3$ & 0,000 & Valid & & Reliable \\
\hline \multirow{3}{*}{$\begin{array}{l}\text { Jaminan } \\
\text { (X3) }\end{array}$} & X3.1 & 0,000 & Valid & \multirow{3}{*}{0,860} & Reliable \\
\hline & $\mathrm{X} 3.2$ & 0,000 & Valid & & Reliable \\
\hline & X3.3 & 0,000 & Valid & & Reliable \\
\hline \multirow{3}{*}{$\begin{array}{l}\text { Empati } \\
\text { (X4) }\end{array}$} & $\mathrm{X} 4.1$ & 0,000 & Valid & \multirow{3}{*}{0,793} & Reliable \\
\hline & $\mathrm{X} 4.2$ & 0,000 & Valid & & Reliable \\
\hline & $\mathrm{X} 4.3$ & 0,000 & Valid & & Reliable \\
\hline \multirow{3}{*}{$\begin{array}{l}\text { Bukti Fisik } \\
\text { (X5) }\end{array}$} & $\mathrm{X} 5.1$ & 0,000 & Valid & \multirow{3}{*}{0,852} & Reliable \\
\hline & $\mathrm{X} 5.2$ & 0,000 & Valid & & Reliable \\
\hline & X5.3 & 0,000 & Valid & & Reliable \\
\hline \multirow{3}{*}{$\begin{array}{l}\text { Kepuasan } \\
\text { Pelanggan } \\
\text { (Y) }\end{array}$} & Y1.1 & 0,000 & Valid & \multirow{3}{*}{0,824} & Reliable \\
\hline & $\mathrm{Y} 1.2$ & 0,000 & Valid & & Reliable \\
\hline & Y1.3 & 0,000 & Valid & & Reliable \\
\hline
\end{tabular}

\section{Uji Asumsi Klasik}

Terdapat empat uji asumsi klasik yang dilakukan pada penelitian ini yaitu uji normalitas, uji autokorelasi, uji multikolinearitas dan uji heteroskedastisitas. Hasil uji asumsi klasik dapat dilihat pada Tabel 2. Pada Tabel 2 dapat diketahui nilai Z-Skewness dan Z-Kurtosis semua variabel bebas maupun terikat bernilai -2 sampai dengan +2 , maka dapat disimpulkan bahwa data berdistribusi normal. Hal 
tersebut sesuai pendapat Nisfiannoor (2009), bahwa data berdistribusi normal jika nilai rasio skewness dan kurtosis berada diantara -2 hingga +2 .

Uji asumsi klasik kedua adalah uji autokorelasi yang dapat dilihat dari nilai Durbin Watson (DW). Pada Tabel 2 menunjukkan nilai DW sebesar 1,704. Berdasarkan Singgih (2002) dalam Sulistiyawan (2008), jika nilai D-W diantara 2 sampai dengan +2 , maka tidak ada autokorelasi. Oleh karena itu, data penelitian ini terbebas dari masalah autokorelasi. Uji asumsi klasik ketiga adalah uji multikolinearitas yang hasilnya dapat dilihat pada kolom nilai VIF di Tabel 2. Nilai VIF untuk kelima variabel bebas $<10$, oleh karenanya dapat ditarik kesimpulan bahwa data sudah terbebas dari masalah multikolinearitas. Hal tersebut sesuai pendapat Siswanto (2015), jika nilai VIF < 10 maka model regresi terbebas dari masalah multikolinearitas.

Uji asumsi klasik yang terakhir adalah uji heteroskesdasitas dan pada penelitian kali ini menggunakan uji Glejser. Hasil uji Glejser berupa nilai signifikan dapat dilihat pada Tabel 2. Menurut Gujarati (2004), jika nilai sig. > 0,05 maka tidak terjadi masalah heteroskedastisitas. Keseluruhan nilai sig. pada Tabel 2 menunjukkan nilai lebih dari 0,05, maka dapat ditarik kesimpulan bahwa data pada penelitian ini sudah terbebas dari masalah heteroskedastisitas.

\section{Uji Hipotesis}

Pada uji hipotesis terdapat tiga uji yaitu uji simultan, uji parsial dan uji determinan. Hasil uji simultan atau uji serempak atau uji $\mathrm{F}$ dapat dilihat pada Tabel 3. Nilai sig. pada Tabel 3 menunjukkan nilai 0,000 yang memiliki arti bahwa secara simultan variabel independen memberikan pengaruh kepada variabel dependen, sehingga $\mathrm{Ha}_{1}$ diterima dan $\mathrm{Ho}_{1}$ ditolak. Sependapat dengan Nugroho (2005), jika nilai Sig. < 0,05 maka variabel independen secara simultan berpengaruh signifikan terhadap variabel dependen. 
Tabel 2. Hasil Uji Asumsi Klasik

\begin{tabular}{|c|c|c|c|c|c|c|c|c|c|}
\hline Variabel & $\begin{array}{c}\text { Z- } \\
\text { Skewness }\end{array}$ & $\begin{array}{c}\text { Z- } \\
\text { Kurtosis }\end{array}$ & Hasil & $\begin{array}{l}\text { Nilai } \\
\text { DW }\end{array}$ & Hasil & VIF & Hasil & Sig. & Hasil \\
\hline $\begin{array}{l}\text { Kehan- } \\
\text { dalan } \\
\text { (X1) }\end{array}$ & 1,125 & -1.64 & \multirow{6}{*}{ Normal } & \multirow{6}{*}{1.704} & \multirow{6}{*}{$\begin{array}{c}\text { Tidak } \\
\text { terjadi } \\
\text { masalah } \\
\text { auto- } \\
\text { korelasi }\end{array}$} & 1,013 & \multirow{6}{*}{$\begin{array}{c}\text { Tidak } \\
\text { terjadi } \\
\text { masalah } \\
\text { multiko- } \\
\text { lineari- } \\
\text { tas }\end{array}$} & 0,673 & \multirow{6}{*}{$\begin{array}{l}\text { Tidak } \\
\text { terjadi } \\
\text { masalah } \\
\text { heteros- } \\
\text { kedas- } \\
\text { tisitas }\end{array}$} \\
\hline $\begin{array}{l}\text { Daya } \\
\text { Tanggap } \\
\text { (X2) }\end{array}$ & $-1,071$ & -1.902 & & & & 1,058 & & 0,449 & \\
\hline $\begin{array}{l}\text { Jaminan } \\
\text { (X3) }\end{array}$ & $-1,793$ & $-1,203$ & & & & 3,018 & & 0,565 & \\
\hline $\begin{array}{l}\text { Empati } \\
\text { (X4) }\end{array}$ & $-1,390$ & $-1,923$ & & & & 2,531 & & 0,163 & \\
\hline $\begin{array}{l}\text { Bukti } \\
\text { Fisik } \\
\text { (X5) }\end{array}$ & $-1,971$ & $-1,912$ & & & & 2,693 & & 0,339 & \\
\hline $\begin{array}{l}\text { Kepuas - } \\
\text { an Pelang } \\
\text {-gan }(\mathrm{Y})\end{array}$ & $-1,726$ & $-1,345$ & & & & - & & - & \\
\hline
\end{tabular}

Tabel 3. Hasil Uji Simultan

ANOVA $^{b}$

\begin{tabular}{|c|c|c|c|c|c|c|}
\hline \multicolumn{2}{|c|}{ Model } & Sum of Squares & df & Mean Square & $\mathrm{F}$ & Sig. \\
\hline \multirow[t]{3}{*}{1} & Regression & 247.685 & 5 & 49.537 & 46.740 & $.000^{\mathrm{a}}$ \\
\hline & Residual & 99.625 & 94 & 1.060 & & \\
\hline & Total & 347.310 & 99 & & & \\
\hline
\end{tabular}

a. Predictors: (Constant), BUKTI FISIK (X5), KEHANDALAN (X1), DAYA TANGGAP (X2), EMPATI (X4), JAMINAN (X3)

b. Dependent Variable: KEPUASAN PELANGGAN $(Y)$

Hasil uji parsial dapat dilihat pada Tabel 4, di mana keseluruhan nilai Sig. untuk kelima variabel independen adalah kurang dari 0,05. Menurut Santosa (2008), jika nilai Sig < 0,05 maka variabel bebas memiliki pengaruh secara parsial 
terhadap variabel terikat. Oleh karena itu, $\mathrm{Ha}_{2}, \mathrm{Ha}_{3}, \mathrm{Ha}_{4}, \mathrm{Ha}_{5}$, dan $\mathrm{Ha}_{6}$ diterima. Keseluruhan variabel independen berpengaruh terhadap variabel dependen secara parsial.

Tabel 4. Hasil Uji Parsial

\begin{tabular}{|c|c|c|c|c|c|c|}
\hline \multicolumn{7}{|c|}{ Coefficients $^{a}$} \\
\hline \multirow{2}{*}{\multicolumn{2}{|c|}{ Model }} & \multicolumn{2}{|c|}{ Unstandardized Coefficients } & \multirow{2}{*}{$\begin{array}{c}\text { Standardized } \\
\text { Coefficients } \\
\text { Beta }\end{array}$} & \multirow[b]{2}{*}{$\mathrm{t}$} & \multirow[b]{2}{*}{ Sig. } \\
\hline & & $\mathrm{B}$ & Std. Error & & & \\
\hline \multirow[t]{8}{*}{1} & (Constant) & -4.038 & 1.295 & & -3.118 & .002 \\
\hline & KEHANDALAN & .125 & .059 & .118 & 2.121 & .037 \\
\hline & $(\mathrm{X} 1)$ & & & & & \\
\hline & DAYA TANGGAP & .140 & .057 & .139 & 2.451 & .016 \\
\hline & $(X 2)$ & & & & & \\
\hline & JAMINAN (X3) & .286 & .106 & .259 & 2.694 & .008 \\
\hline & EMPATI (X4) & .290 & .100 & .256 & 2.918 & .004 \\
\hline & BUKTI FISIK (X5) & .468 & .117 & .363 & 4.005 & .000 \\
\hline
\end{tabular}

a. Dependent Variable: KEPUASAN PELANGGAN (Y)

Besarnya pengaruh variabel independen terhadap variabel dependen dapat dilihat dari nilai $\mathrm{R}$ square pada Tabel 5 yang merupakan hasil uji determinan. Nilai $\mathrm{R}$ square sebesar 0,713 memberikan arti bahwa variabel independen berpengaruh terhadap variabel dependen sebesar 71,3\%. Menurut Ghozali (2009) dalam Ma'arif (2013), nilai $\mathrm{R}$ square yang mendekati satu berarti variabelvariabel independen memberikan hampir semua informasi yang dibutuhkan untuk memprediksi variabel dependen.

Tabel 5. Hasil Uji Determinan

\begin{tabular}{|l|r|r|r|c|}
\hline \multicolumn{7}{|c|}{ Model Summary } \\
\hline 1 & $\mathrm{R}$ & $\mathrm{R}$ Square & $\begin{array}{c}\text { Adjusted R } \\
\text { Square }\end{array}$ & $\begin{array}{c}\text { Std. Error of the } \\
\text { Estimate }\end{array}$ \\
\hline & $.844^{\mathrm{a}}$ & .713 & .698 & 1.029 \\
\hline
\end{tabular}




\begin{tabular}{|l|r|r|r|c|}
\hline Model & $\mathrm{R}$ & R Square & \multicolumn{1}{|c|}{$\begin{array}{c}\text { Adjusted R } \\
\text { Square }\end{array}$} & $\begin{array}{c}\text { Std. Error of the } \\
\text { Estimate }\end{array}$ \\
\hline 1 & $.844^{\mathrm{a}}$ & .713 & .698 & 1.029 \\
\hline
\end{tabular}

a. Predictors: (Constant), BUKTI FISIK (X5), KEHANDALAN (X1), DAYA TANGGAP (X2), EMPATI (X4), JAMINAN (X3)

\section{KESIMPULAN DAN SARAN}

\section{Kesimpulan}

Berdasarkan penelitian yang telah dilakukan kepada 100 responden pelanggan Supermarket Sea Mart di Kota Blitar, serta hasil dari beberapa pengujian, diperoleh kesimpulan sebagai berikut:

1. Terdapat pengaruh variabel kehandaln (X1), daya tanggap (X2), jaminan (X3), empati (X4) dan bukti fisik (X5) terhadap variabel kepuasan pelanggan Supermarket Sea Mart di Kota Blitar (Y) secara simultan.

2. Terdapat pengaruh variabel kehandaln (X1), daya tanggap (X2), jaminan (X3), empati (X4) dan bukti fisik (X5) terhadap variabel kepuasan pelanggan Supermarket Sea Mart di Kota Blitar (Y) secara parsial.

\section{Saran}

Supermarket Sea Mart di Kota Blitar dapat meningkatkan kepuasan pelanggan dengan meningkatkan lagi bukti fisik yang telah ada saat ini. Hal tersebut dikarenakan dari kelima variabel independen yang memiliki nilai kepuasan tertinggi adalah variabel bukti fisik. Meningkatkan bukti fisik seperti memberikan fasilitas (fisik) yang lebih baik kepada pelanggan, maka kepuasan pelanggan Supermarket Sea Mart di Kota Blitar akan semakin tinggi.

\section{DAFTAR PUSTAKA}

Arikunto, S. 2002. Metodologi Penelitian. PT. Rineka Cipta. Jakarta.

Bahri, S. dan Zamzam, F. 2015. Model Penelitian Kuantitatif Berbasis SEMAMOS. Deepublish. Yogyakarta. 
Budiantara, Z. 2014. Manajemen Riset Pemdekatan Komputasi 'Statistika. Deepublish: Yogyakarta.

Ghozali, I. 2006. Aplikasi Analisis Multivariat dengan Program SPSS. Penerbit Grafindo. Jakarta.

Hamdi, A. S. dan Bahruddin E. 2014. Metode Penelitian Kuantitatif Aplikasi dalam Pendidikan. Deepublish. Yogyakarta.

Hermawan, A. 2005. Penelitian Bisnis: Paradigma Kuantitatif. PT. Grasindo. Jakarta.

Hasan, M.I. 2002. Pokok-Pokok Materi: Metodologi Penelitian dan Aplikasinya. Ghalia Indonesia. Jakarta.

Jasfar, F. 2002. Manajemen Jasa: Pendekatan Terpadu. Lembaga Penerbit Fakultas Ekonomi Trisakti. Jakarta.

Kotler, P. Manajemen Pemasaran. Terjemahan oleh Benyamin Molan. 2008. PT. Prehalindo. Jakarta.

Lupiyoadi, R. 2001. Manajemen Pemasaran Jasa. Edisi Pertama. Salemba Empat. Jakarta.

Ma'arif, S. 2013. Analisis Faktor-Faktor yang Mempengaruhi Pendapatan Pedagang Pasar Bandarjo Ungaran Kabupaten Semarang. Skripsi. Sarjana Ekonomi. Universitas Negeri Semarang. Semarang.

Nisfiannoor, M. 2009. Pendekatan Statistika Modern untuk Ilmu Sosial. Salemba Humanika. Jakarta.

Nisfiannoor, M., dan Valentini, V. 2006. Identity Achievement dengan Intimacy Pada Remaja SMA. Jurnal Provitae. 2(1):9-10.

Nugroho, B. 2005. Strategi Jitu Memilih Metode Statistik Penelitian dengan SPSS. Andi Offset. Yogyakarta.

Parjanti, E., Hendra, K., dan Nurlela, S. 2014. Pengaruh Sistem Informasi Akuntansi, Gaya Kepemimpinan dan Kompleksitas Tugas Terhadap Kinerja Karyawan. Jurnal Paradigma. 12(1):57-70.

Santosa, S. 2008. SPSS Versi 15.0 for Windows: Mengolah Data Statistik Secara Profesional. Penerbit Elex Media Komputindo. Jakarta. 
Santosa, P., dan Ashari. 2005. Analisis Statistik dengan Microsoft Excel dan SPSS. Andi Offset. Yogyakarta.

Setyani, H. 2015. Pengaruh Marketing Mix Terhadap Keputusan Pembelian Konsumen di Toko Alat Tulis Hadi Sutrisno Putra 2 Limpung. Skripsi. Sarjana Ekonomi Islam. Universitas Islam Negeri Walisongo. Semarang.

Siregar, S. 2013. Metode Penelitian Kuantitatif. Kencana Prenada Media Group. Jakarta.

Siswanto. 2015. Belajar Sendiri SPSS 22. Andi Offset. Yogyakarta.

Soegoto, E. S. 2013. Marketing Research:The Smart Way to Solve a Problem. Elex Media Komputindo. Jakarta.

Sugiyono. 2005. Statistik untuk Penelitian. Bandung. Penerbit Alfabeta.

Sugiyono. 2011. Metode Penelitian Administrasi. Alfabeta. Bandung.

Sugiyono. 2013. Statistika untuk Penelitian. Alfabeta. Bandung.

Sulistiyawan, F. 2008. Pengaruh Retailing Mix Terhadap Keputusan Pembelian Pada Alfamart di Jl. Gajayana Malang. Skripsi. Sarjana Ekonomi. Universitas Islam Negeri Malang. Malang.

Trihendradi. 2013. Langkah Mudah Menguasai SPSS 21. Andi Offset. Yogyakarta.

Umar. H. 2002. Riset Pemasaran dan Perilaku Konsumen. Cetakan Kedua. Gramedia. Pustaka Utama. Jakarta.

Zulfikar. 2016. Pengantar Pasar Modal dengan Pendekatann Statistika. Deepublish Publisher. Yogyakarta. 